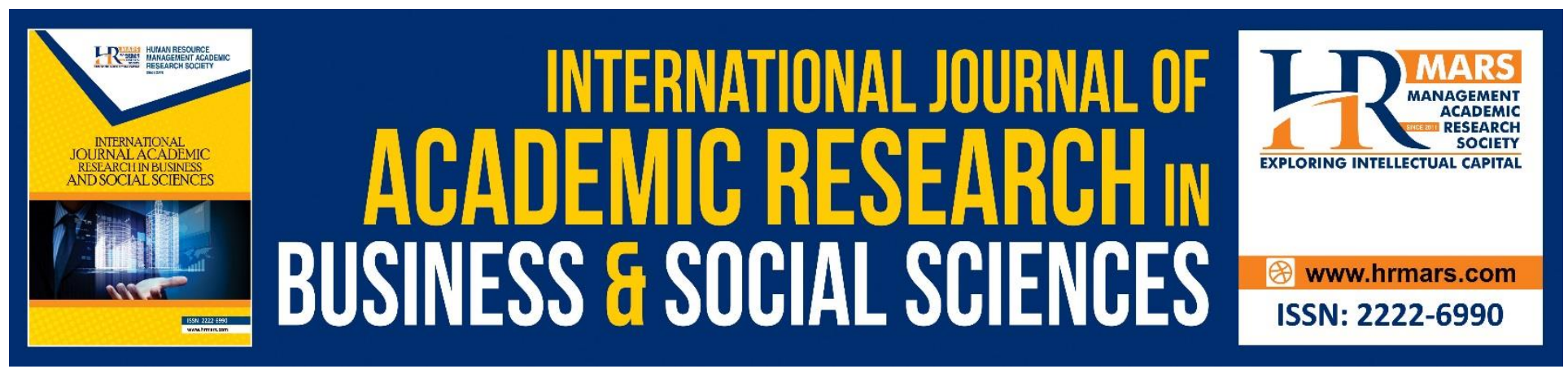

\title{
Youth Leadership Development through Training Transfer and Mentoring
}

\author{
Muaza Shifa Rumeli, Mohd Mursyid Arshad, Ismi Arif Ismail, Ahmad Aizuddin \\ Md Rami
}

To Link this Article: http://dx.doi.org/10.6007/IJARBSS/v11-i15/10652

DOI:10.6007/IJARBSS/v11-i15/10652

Received: 08 May 2021, Revised: 13 June 2021, Accepted: 29 June 2021

Published Online: 24 July 2021

In-Text Citation: (Rumeli et al., 2021)

To Cite this Article: Rumeli, M. S., Arshad, M. M., Ismail, I. A., \& Rami, A. A. M. (2021). Youth Leadership Development through Training Transfer and Mentoring. International Journal of Academic Research in Business and Social Sciences, 11(15), 272-284.

Copyright: (C) 2021 The Author(s)

Published by Human Resource Management Academic Research Society (www.hrmars.com)

This article is published under the Creative Commons Attribution (CC BY 4.0) license. Anyone may reproduce, distribute, translate and create derivative works of this article (for both commercial and non-commercial purposes), subject to full attribution to the original publication and authors. The full terms of this license may be seen at: $\underline{\text { http://creativecommons.org/licences/by/4.0/legalcode }}$

Special Issue: Empowering Youth and Community Wellbeing for Sustainable Development, 2021, Pg. 272 - 284 http://hrmars.com/index.php/pages/detail/IJARBSS JOURNAL HOMEPAGE

Full Terms \& Conditions of access and use can be found at http://hrmars.com/index.php/pages/detail/publication-ethics 


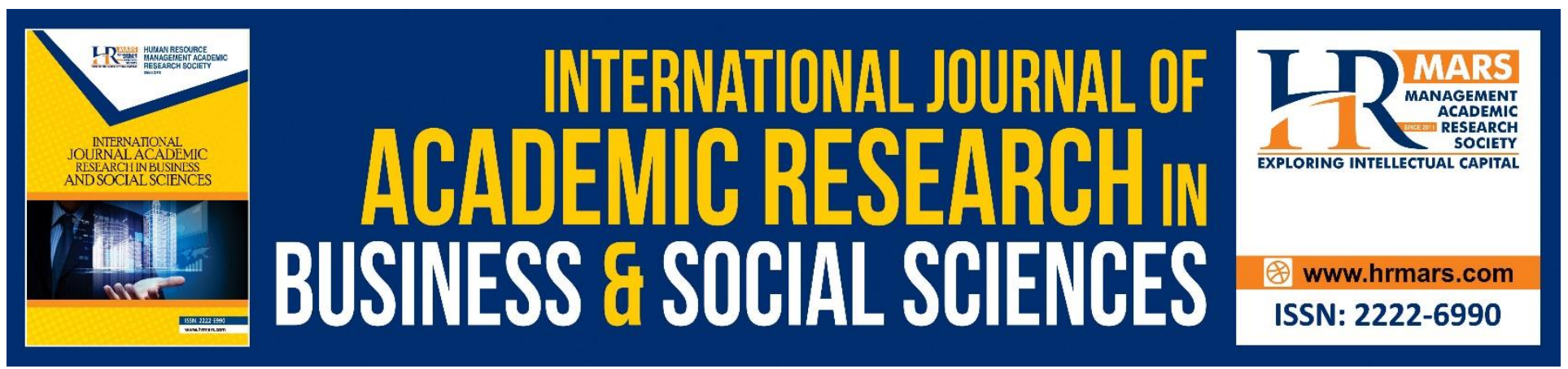

\title{
Youth Leadership Development through Training Transfer and Mentoring
}

\author{
Muaza Shifa Rumeli \\ Faculty of Educational Studies, Universiti Putra Malaysia, 43400, Serdang, Selangor Darul Ehsan, \\ Malaysia \\ Email: dean.educ@upm.edu.my
}

\section{Mohd Mursyid Arshad}

Faculty of Educational Studies, Universiti Putra Malaysia, 43400, Serdang, Selangor Darul Ehsan, Malaysia, Institute for Social Sciences Studies, Universiti Putra Malaysia, 43400, Serdang, Selangor

Darul Ehsan, Malaysia.

Email: m_mursyid@upm.edu.my

\section{Ismi Arif Ismail}

Faculty of Educational Studies, Universiti Putra Malaysia, 43400, Serdang, Selangor Darul Ehsan, Malaysia, Institute for Social Sciences Studies, Universiti Putra Malaysia, 43400, Serdang, Selangor

Darul Ehsan, Malaysia.

Email: ismi@upm.edu.my

\author{
Ahmad Aizuddin Md Rami \\ Institute for Social Sciences Studies, Universiti Putra Malaysia, 43400, Serdang, Selangor Darul \\ Ehsan, Malaysia. \\ Email: ahmadaizuddin@upm.edu.my
}

\begin{abstract}
Training and training transfer are issues in the field of human resource development. Training is a necessity for all employees including youth leaders. Training transfer is a way to indicate the actions of the participants after attending the training program. Youth leadership is an element critically needed in nation building agenda. The establishment of youth leadership will form the line of successors that will maneuver the socioeconomic landscape. The involvement of new youth leadership talent can be enhanced through wider exposure and professional training, including training transfer and mentoring. This article attempts to understand the definition of youth leaders, transfer training and explore the challenges and expectations of leadership in the context of youth development. The objective is also to explore youth leadership development through training transfer and mentoring.
\end{abstract}


INTERNATIONAL JOURNAL OF ACADEMIC RESEARCH IN BUSINESS AND SOCIAL SCIENCES

Vol. 11, No. 15, Empowering Youth and Community Wellbeing for Sustainable Development, 2021, E-ISSN: 2222-6990 @ 2020 HRMARS

Keywords: Training, Training Transfer, Youth Development, Human Resource Development

\section{Introduction}

Human resource development contains three main parts which are training and development, organization development and career development These three components are important for human resource development (McLagan, 1996). Work performance is important in determining the quality and reputation of an organization. A more strategic performance measurement system will assist management in translating organizational strategies into action plans to be more advanced and competitive in achieving vision and mission (Zakaria et al.,2020). It is a necessity for an organization to have training and development when they aim to increase the efficiency and competency. Leadership is the most important factor in ensuring efficiency and effectiveness in an organization. A leader is the driver of an organization who integrates all the factors in the organization strategically to achieve the goals set and the objectives. There are leaders who have leadership characteristics naturally but for most officers, these leadership characteristics need to be developed by the organization through a systematic and planned leadership development program. The failure of an organization to develop a line of backup leaders efficiently and committed to leading the organization can lead to adverse implications for the organization in the future (Mahtar, 2005). In this regard, leadership development programs have been implemented in the public sector to ensure that highperforming and potential public officials are provided with appropriate exposure, training and guidance to develop and cultivate leadership characteristics to enable them to take over leadership service in the future. Training is one of the systematic practices in the field of human resources. It can benefits individuals, teams, organizations and communities to improve individual, team quality, and organizational effectiveness (Aguinis \& Kraiger, 2009).

Training transfer is a major issue in training because it symbolizes the effectiveness of the training program conducted and the return on investment to the organization. Training transfer is also a process where the transfer of knowledge, behavior and skills occurs after the staff undergoes the training program. Blume et al.(2017). Training transfer is fundamentally about the impact of trained on relevant behavior at work (job performance) to achieve work objectives or outcomes.Youth are the machinery of national change towards trend development and activity in society and the main determinant of community growth and development (Redmond \& Dolan, 2016). Youths are always energetic and ready to go further to achieve their goals. The government has made various efforts to improve youth development in the country (Sabri \& Fuad, 2016). The National Youth Development Policy defines youth as individuals between the ages of 15 and 40 years old (Youth Development and Youth Development Organization, 2007). The Character of Youth Malaysia is a religious personality, tends towards conservative, family oriented, consumers who are dynamic inclined to technology, diligent, optimistic about the future that is shrouded in anxiety, and ready in any situation to be approached.

\section{Literature Review}

\section{Training and Development}

Globalization, technological advancements and talent wars called for leveraging training for improved individual and organizational effectiveness (Muduli \& Trivedi, 2020). Human resource development defines training as a systematic set and planning on organisational activities to be given to employees by providing opportunities to learn, meeting current skills requirements in order to achieve job 
demands nowadays and future. One of the functions of human development is also to provide training, developing employees as well as emphasising the changing knowledge, skills and abilities of individuals (Desimone, 2002). According to Aziz (2002) training in the organisation is a continuous learning process compiled to transform employees' attitude, knowledge and skills so that their work performance can be improved. Effective training programmes can benefit organizations and employees. The actual success of the training program is dependent on the level of capabilities, knowledge, skills and employee behaviour and can be applied and used to increase employee productivity as well as achieve organizational goals. Thus, today's organisation has recognised the importance of training, training programmes have been developed and carefully organised to enable employees who received the training to apply everything they learnt.

Training programmes are said to be effective when the programme is able to change employees' behaviour after they return to work after attending a training programme or course. Gegenfurtner et al. (2019) Training sessions are designed so that trainees can acquire skills, as well as transfer and use those skills in real-world contexts, such as workplaces. Training is also defined as a planned learning process designed to change the behaviour, knowledge and attitude of individuals. While other definitions say training is a learning programme designed to deliver training both internally and externally to enhance the effectiveness and efficiency of each individual within the organisation (Scobby, 2001). Training design refers to the way training programs are designed, delivered and assessed and determining whether the training is relevant to the work of the trainees (Maina, 2016).

Generally, training is seen to lead to increase productivity, increase satisfaction in undertaking jobs and effectiveness in carrying out the tasks assigned to employees. Good training is also a systematic training that can be implemented and meets the objective requirements of the organisation as prescribed. It should be well planned and compiled so that there is effectiveness when the training received can be applied in the workplace by the employees perfectly. The need for training is also seen as a key area in developing an institution or organisation. Training is a well-planned programme designed to improve performance at individual and group levels. As a result, it is able to improve the performance of an organisation and be competitive.

\section{Concept of Training Transfer}

Training transfer is a training transfer is a process where individual transfer their knowledge, skills and attitudes to the workplace and from the results of learning from the training, they can demonstrate the quality of services to the customers. Yaghi and Bates (2020) Most organization compete to optimize the utilization of available resources, which increases the pressure on staff to improve their leadership skills in managing organization policies. They acquire and apply the best leadership knowledge, skills and abilities (KSA). In Human Resource Development (HRD), this process is called 'learning transfer' or 'training transfer' (Poell, 2017). Research and practice on training has acknowledged the role of transferring knowledge and skills from a training programs to work place, otherwise known as "training transfer" for better training effectiveness (Muduli \& Raval, 2018; Singh et al., 2019). Ford, Baldwin \& Huang (2010) stated the transfer of training refers to the process of applying knowledge, skills and attitudes gained throughout the training and has moved the results to the workplace. 
Gegenfurtner, et al (2019). Motivational influences are important predictors of training effectiveness and transfer of training to the workplace. Training transfer is a continuation application of the knowledge and skills acquired during training to be practiced in the workplace. Zakaria et.al (2020) training transfer occurs if the employee continuously practices all that knowledge received and learned while undergoing training to improve performance in the workplace. The transfer of positive training will have a positive impact on the strategic work performance of an individual in the organization.

Some of the skills available from the course can only be transferred to the workplace effectively in the event of cultural changes in the workplace. The managers' involvement before, after and in some cases during training, ensures that every employee gets sufficient time to practice what they learnt during the course and manage the transition takes place from course to work. The focus of this study is on the transfer of training and determining the relationship of individual factors and work environment factors through independent variables capabilities, motivation, personality, organizational culture and administrative support. The transfer of training benefits both the employee and the entire organization because it causes learning to last and accumulate over a long period of time (Soerensen et al., 2017). It consists in the direct and indirect application of KSA that an organization member has acquired during work-related training (James, 2017). Cascio (2003) states training transfers refer to the use of knowledge, skills and conduct in training. This training transfer can be influenced by the atmosphere for transfer, manager support, colleague support, opportunities using learned capabilities and technological support. According to Cascio (2003) another transfer of this exercise can occur either positive, negative or neutral.

According to Baldwin \& Ford, (1988) employee characteristics such as personality, employee ability and motivation have been identified as factors affecting training transfer. Employee capabilities are acquired knowledge, basic knowledge and experience. Then the ability of employees to practice back what was learnt while receiving training to real employment spaces. Subsequently, it was able to maintain the knowledge and skills learned for a certain period of time. Environmental factors refer to the atmosphere an employee receives training. Based on Baldwin and Ford (1988), two aspects covered in the environment are organisational support and the opportunity to practice back what has been learned. Organisational support is like gaining inspiration and appreciation and providing appropriate facilities so that employees can reuse the knowledge and skills that have been learned. 
INTERNATIONAL JOURNAL OF ACADEMIC RESEARCH IN BUSINESS AND SOCIAL SCIENCES

Vol. 11, No. 15, Empowering Youth and Community Wellbeing for Sustainable Development, 2021, E-ISSN: 2222-6990 @ 2020 HRMARS

The definition of training transfer for other studiers can be formulated such as Figure 2.

Researcher Name \& Year Definition of Training Transfer

Norazman Irmawati and Siti Aisyah Panatik (2015)

Generate knowledge, skills and ability in the workplace.

Noorizan, Nur Fareehan Afzan, Norfazlina and Sharidatul Akma (2015)

Employees are motivated to apply what is learned at training to work without coercion

Zumrah, Boyle and Fein (2012)

Employees who have gained and learned new knowledge, skills and attitudes from the training that they have attended, they are able to utilise their new knowledge, skilled and workplace attitude after training.

Laker and Powell, (2011)

Park and Wentling (2007)

Training transfer is the extent to which what is learned in training and used in the workplace as well as how to improve performance related to work.

Training transfer is one of the key indicators to measure the success of learning at work

Velada and Caetano(2007)

Burke and Hutchins (2007)

Hawley and Barnard(2005)

Training transfer refers to the extent to which employees regularly use the knowledge, skills, behaviours, and attitudes learned in training to the workplace.

Training transfer refers to the use of knowledge and skills acquired during training to thworkplace.

Employee applications to work in what ways are learned in the training program.

Noe $(2002 ; 2005)$

Goldstein and Ford(2002)

Training transfer is an employee's appropriation of what he learns about whether his knowledge, skills, attitude or cognitive strategies, effectively and continuously in his work.

The meaning of training transfer is divided into two, direct transfer means employees' ability to apply learning outcomes in situations and places of training and secondly, indirect transfers mean the ability of employees to new apply knowledge, skills and abilities, as well as apply them in an outof-training environment. 
INTERNATIONAL JOURNAL OF ACADEMIC RESEARCH IN BUSINESS AND SOCIAL SCIENCES

Vol. 11, No. 15, Empowering Youth and Community Wellbeing for Sustainable Development, 2021, E-ISSN: 2222-6990 @ 2020 HRMARS

Bates, (2000) and Ramsay(1996)

Baldwin and Ford (1988), Foxon

Elangovan and Karakowsky, (1999)

Broad and Newstrom (1992)
Training transfer is the process of bringing more skills and knowledge learned from training to work situations

(1993), Training transfer is the ability to leverage on the knowledge, experience and attitude learned during training to the workplace.

Training transfer is an effective application continuously in knowledge, skills, behaviour, cognitive strategies obtained in the workplace

Haslina Zakaria (2013)

\section{Generation Gap in Leadership}

Leadership mentoring takes place in most organizations to fulfill the purpose of preparing future leaders and successors of the organization (Smolter, 2011; Murphy, 2012). Usually, mentors come from a different generation than the protégé (Chen \& Krauskopf, 2013) and this does not necessarily depend on age (Harvey et al., 2009). Adult mentors may not experience any problem to socialize and communicate with youths as their proteges, but they may have different interpretations during the two-way communication (Reagan- Porras, 2013). In the context of today's youth leadership development, proteges born between 1980 to 2000 are known as Generation $Y$ or Millennial (Hershatter \& Epstein, 2010), compared to the more senior mentors from Generation X or Baby Boomers (Dannar, 2013).

The generation differences in mentoring bring a great implication that influences the role of leadership in the medical field and healthcare (Hershatter \& Epstein, 2010). Each of them had different environmental experiences that shaped varied expectations and actions (Chen \& Krauskopf, 2013), and leadership patterns (Smolter, 2011). The generation gap in youth leadership mentoring allows for a deeper exploration on how the process happens effectively which includes the compatibility between mentor and protégé from different generations. This is because, according to Ragins and Kram (2007) mentoring theory, mentoring process is not static, it portrays different functions, experiences and forms of interaction that may be expanded in youth development.

Youth potential in leadership can be amplified through developmental programmes (MacNeil, 2006; Hastings, Human, \& Bell, 2011; Reagan-Porras, 2013). The emphasis on reciprocal learning through mentoring requires proteges to develop positive values through the roles they play in mirroring what have been done by their mentors.

\section{Positive Youth Development (PYD) in the Training Transfer}

From the youth leadership aspect, knowledge formation process, behaviour and positive attitude of the participants cultivated from the leadership development programmes may be an indicator of the production of positive youth development (Lerner, 2005; Silbereisen \& Lerner, 2007; Lerner et al., 2011). Therefore, the aspect of planning youth development programmes is encouraged to take into 
account the current needs of youths (Cullen \& Bradford, 2012). A proper planning of developmental programmes will explain in detail the learning outcomes based on the objectives reached. This is the main element in planning leadership developmental programmes that focuses on youths. Effective mentoring enables the development of youth potential by providing them with the opportunity to develop life and leadership skills, which in turn, will enhance positive youth development (Lerner et al., 2013). With that, youths may give their contributions through youth development programmes as a medium to create an ongoing relationship with their mentors who have provided the opportunity for skills development of the youths (Karcher \& Hansen, 2013).

Positive youth development (PYD) perspective basically combines two main ideas. The first perspective is that youths possess the strength as displayed through the development of their ability in cognitive, emotion, social and behavioural changes (Lerner, Brittian \& Fay, 2007; Phelps et al., 2009; Gestsdottir et al., 2011). Furthermore, the second perspective is the hypothesis assuming that the PYD element will increase when the youth strength is compatible with the strength to react to their surrounding (Benson et al., 2006), for a healthy development in their ecology. The individual development process in the PYD context involves adaptation of developmental regulations between youth strength and asset development within a particular ecology (Phelps et al., 2009).

The PYD perspective initially stems from the positive psychological concept, which appears as a result to comparisons made by psychologists and biologists studying plasticity in the development process emerging from the combination process. To relate the concept of knowledge engineered in this study, the system of theory development such as individual contextualism development has emphasized on plasticity that exist in human development. Specifically, the perspective towards PYD may be narrowed down to the following:

"The Positive Youth Development (PYD) perspective is an orientation to young people that has arisen because of interest among developmental scientists in using development systems, or dynamic, models of human behavior and development for understanding the plasticity of human development and the importance of relations between individuals and their real-world ecological settings as bases of variation in the course of human development"

(Sibereisen \& Lerner, 2007, p.3)

The term 'plasticity' is a potential for a more systematic change in human development, which instills positive elements (Lerner et al., 2005; Lerner, Brittian \& Fay, 2007). Therefore, the process requires internal and external support. According to Theokas et al. (2005), the combination of internal and external situations for the development of PYD elements above mentioned are known as the ecological and individual assets (Lerner et al., 2012). The internal asset is an element that guides youths to make choices related to their strengths, that is their hopeful future expectation, internal self-regulation and positive school engagement. Meanwhile, the external assets are ecological assets mostly related to positive experiences obtained from others, and the institutions they are involved with (Lerner et al., 2012). This may lead to individual joined benefit as the context of relationship with PYD consist of five elements ' $5 C^{\prime}$ ' (Lerner et al., 2005), illustrated in Figure 1 as follows: 
INTERNATIONAL JOURNAL OF ACADEMIC RESEARCH IN BUSINESS AND SOCIAL SCIENCES

Vol. 11, No. 15, Empowering Youth and Community Wellbeing for Sustainable Development, 2021, E-ISSN: 2222-6990 @ 2020 HRMARS

Figure 1: The relational, developmental systems model of Positive Individual involved in PYD (Lerner et al., 2005, p.7)

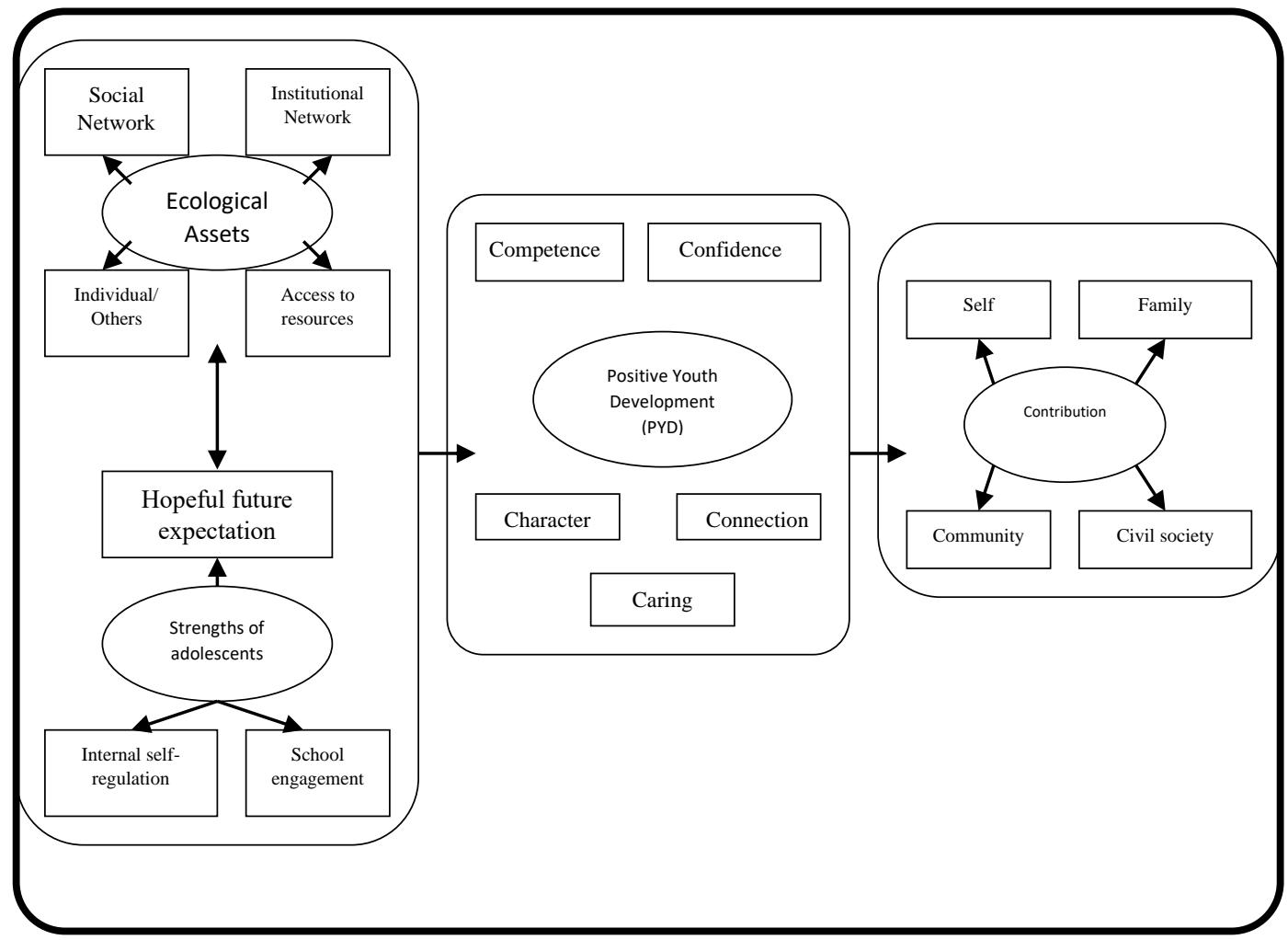

Theoretically, the ecological assets are associated with the developmental process of positive youths, consisting of the ' $5 \mathrm{Cs}$ ' that encourage positive behaviour among youths (Lerner, Brittian \& Fay, 2007). Based on the works of Lerner et al. (2005), there are several specific steps that could be taken by the mentors to develop all the five ' $C$ ' elements within their protégé to ensure a more effective process in youth development. The theory of developmental systems explains that the changes in protégé development is assisted by the mentors by placing positive development as one of the life expectancy process whereby the individual and the context (related environment) are dynamically combined throughout the mutually beneficial interaction in mentoring (Lerner, 2004: DuBois et al., 2011). When the individual and potential contexts for plasticity in human development to occur are acknowledged, this will directly lead to building positive individual potential which includes the aspects of healthcare (Larson, 2006). Therefore, the developmental system theory is also embedded in the youth development process, which is linked to positive youth development (Theokas et al., 2005). Through training transfer and mentoring, youths are given the opportunity to develop skills, shape youth leadership and continuity hence maintain the relationship between the youths (protégé) and adults (mentor). The advantage obtained by the youths through leadership mentoring is associated with the effective youth development criteria. Besides that, it provides the opportunity for the youths to gain access through the ecological asset via the community they are involved in and this will directly develop each of the ' $5 \mathrm{Cs}$ ' element in developing positive youths, which in the end shall be the contribution made by the youths (Lerner et al., 2011; Lerner et al., 2012).

Training conducted very compact. Participants learned theoretically and practically at once. The filling of programmes covers all aspects and is complete according to the needs of the participants. Based on observation, the facilitator provides an opportunity for participants to communicate and do 
discussions with other friends. Meanwhile, the study found that the training and transfer process not only occurred during the program, but also when the participants returned to the workplace, the learning process continued. Under these circumstances, the transfer of learning program participants is through real workplace situations.

\section{Conclusion and Recommendation}

In order to achieve career success in this education, all parties concerned should pay attention to the development and improvement of individuals such as self-efficiency, self-esteem, work priorities, networking and organizational socialization. Therefore, HRD's initiatives in organizations such as training, organization development and career development should be geared towards strengthening themselves as individuals such as the aforementioned characteristics. In line with the above development efforts, the organization needs to promote a continuous learning culture to facilitate and strengthen the employee's transition to current performance. A learning-oriented organization can inspire all employees to accelerate self-learning. Overall, it can be concluded that training transfer is a new knowledge transfer process, skills and behavior obtained through training to the actual workplace. Mozammel (2019) training transfer is a function that attains influence from three broad aspects trainee characteristics, work environment, and training design. The literature on training transfer has sadly provided little value for practitioners as to how they can help foster transfer of training. The professional development program particularly the future leaders, is an exercise in staff services and development, aimed at enhancing knowledge and skills and considered a systematic process in creating the incidence of leaders. According to Delgado (2002), youth developmental process should identify the needs and competency required by youths in preparing youths as successful adults, and not only seeing youths as individuals without potentials. The PYD approach views youths as resources, and develops their strength and ability in the community. Based on this association, the relationships between individual and ecological assets that have been developed have increased youths' potential (Lerner et al., 2012). This may be extended to the context of youth leadership development from training transfer and mentoring.

\section{References}

Aziz, A. B. (2002). Pengurusan Sumber Manusia.Konsep, Isu dan Pelaksanaan.Universiti Sains Malaysia.

Sabri, A. Z., \& Fuad, A. Z. (2016). Pemantapan Kepimpinan dalam Pembangunan Belia di Malaysia. Journal on Leadership \& Policy, 1, 39-47.

Aguinis, H., \& Kraiger, K. (2009). Benefits of Training and Development for Individuals and

Teams, Organizations, and Society. Annual Review of Psychology, 60(1), 451-474.

Baldwin, T. T., \& Ford, J. K. (1988). Transfer of training: A review and direction for future research. Personnel Psychology, 41, 63-105.

Benson, P. L., Scales, P. C., \& Syvertsen, A. K. (2011). The contribution of the developmental assets framework to positive youth development theory and practice. In R. M. Lerner, J. V. Lerner, \& J. B. Benson (Eds.). Advances in child development and behavior. (pp. 125-228). Elsevier Publishing.

Blume, B. D., Kevin F. J., Surface, E. A., \& Olenick, J. (2017). A dynamic model of training transfer. Human Resource Management Review.

Brian D. B., J. Kevin, F., Timothy, T. B., \& Jason L. H. (2010). Transfer of Training: A Meta-Analytic Review. Journal of Management, 36, 1065-1105. 
INTERNATIONAL JOURNAL OF ACADEMIC RESEARCH IN BUSINESS AND SOCIAL SCIENCES

Vol. 11, No. 15, Empowering Youth and Community Wellbeing for Sustainable Development, 2021, E-ISSN: 2222-6990 @ 2020 HRMARS

Broad, M. L., \& Newstrom, J. W. (1992). Transfer of Training: Action Packaged Strategies to Ensure High Payoff from Training Investment. Addison-Wesley Publishing Company.

Burke, L. A., \& Hutchins, H. M. (2007). Training transfer: An integrative literature review. Human resource development review, 6(3), 263-296.

Cascio, W. F. (2003). Changes in workers, work, and organizations. In W. Borman, R. Klimoski, \& D. Ilgen (Eds.), Handbook of psychology. Volume 12: Industrial and organizational psychology: 401- 422. New York: Wiley.

Chen, B., \& Krauskopf, J. (2013). Integrated or disconnected? Examining formal and informal networks in a merged nonprofit organization. Nonprofit Management \& Leadership, 23(3), 325-345.

Dannar, P. R. (2013). Millennials: What they offer our organizations and how leaders can make sure they deliver. The Journal of Values-Based Leadership, 6(1), 1-11.

Desimone, R. L., Werner, J. M., \& Hams, D. M. (2002). Human resource development. 3rd ed. United States of America: Harcourt College Publishers.

Delgado, M. (2002). New frontiers foryouth development in the twenty-first century revitalizing youth development. New York: Columbia University Press.

Gegenfurtner, A., Knogler, M., \& Schwab, S. (2019). Transfer interest: measuring interest in training content and interest in training transfer. Human Resource Development International, 1-22.

Gestsdottir, S., Urban, J. B., Edmond, P., Lerner, J. V, \& Lerner, R. M. (2011). Intentional SelfRegulation, Ecological Assets, and Thriving in Adolescence: A Developmental Systems Model, (133), 61-76.

Haslina, Z. (2013). Faktor individu dan faktor persekitaran yang mempengaruhi pemindahan latihan terhadap pencapaian akademik dalam kalangan pelajar fakult Kejuruteraan Elektrik..Universiti Tun Hussein Onn Malaysia.

Hershatter, A., \& Epstein, M. (2010). Millennials and the world of work: An organization and management perspective. Journal of Business and Psychology, 25, 211-223.

Irmawati \& Aisyah, S. (2013).Toward Understanding the Factors of Learning Transfer in Malaysia. Prosiding PERKEM VIII, Jilid 2, 861-871. Universiti Teknologi Malaysia.

James, M. A. (2017), 'A practical tool for evaluating the potential of ESOL textbooks to promote learning transfer'. TESOL Journal, 8(2), 385-408.

Karcher, M. J., \& Hansen, K. (2013). Mentoring and positive youth development. In D. L. DuBois, \& M. J. Karcher (Eds.), The handbook of youth mentoring (2nd ed.). (pp. 63-82). Thousand Oaks: Sage Publications Inc.

Larson, R. (2006). Positive Youth Development. Willful Adolescents and Mentoring, 34(6), 677-689.

Lerner, R. M. (2009). The positive youth development perspective: Theoretical and empirical bases of a strength-based approach to adolescent development. In C. R. Snyder and S. J. Lopez (Eds.), Oxford Handbook of Positive Psychology (2nd ed., pp. 149-163). Oxford, England: Oxford University Press.

Lerner, R. M., Bowers, E. P., Geldholf, G. J., Gestsdottir, S., \& Desouza, L. (2012). Promoting positive youth development in the face of contextual changes and challenges: The roles of individual strengths and ecological assets. New Directions for Youth Development, 135(1), 119-28.

Lerner, R. M., Brittian, A., \& Fay, K. (2007). Mentoring: A Key Resource for Promoting Positive Youth Development. Research in Action, 1(1), 3-15.

Lerner, R. M., Lerner, J. V., Lewin-Bizan, S., Bowers, E. P., Boyd, M., Mueller, M., Schmid, K., \& Napolitano, C. (2011). Positive youth development: Processes, programs, and problematics. Journal of Youth Development, 6(3), 40-64. 
Lerner, R. M., Napolitano, C. M., Boyd, M. J., Mueller, M. K., \& Callina, K. S. (2013). Mentoring and positive youth development. In D. L. DuBois, \& M. J. Karcher (Eds.), The handbook of youth mentoring (2nd ed.). (pp. 17-27). Thousand Oaks: Sage Publications Inc.

Lerner, R. M., Lerner, J. V., Almerigi, J., Theokas, C., Phelps, E., Gestsdottir, S., Naudeau, S., Jelicic, H., Alberts, A. E., Ma, L., Smith, L. M., Bobek, D. L., Richman-Raphael, D., Simpson, I., Christiansen, E. D., \& von Eye, A. (2005). Positive youth development, participation in community youth development programs, and community contributions of fifth grade adolescents: Findings from the first wave of the 4-H study of positive youth development. Journal of Early Adolescence, 25(1): 17-71.

MacNeil, C. A. (2006). Bridging generations: Applying "adult" leadership theories to youth leadership development. New Directions for Youth Development, 109(1), 27-43.

Mahtar. (2005). Pembangunan Kepimpinan Dalam Organisasi . Jurnal Pengurusan Awam Jilid 4.

Maina, R. N. (2016). Predictors of transfer of learning from education management training to the workplace among principals, head teachers and deputy head teachers in Kiambu county. Ph.D. Thesis. (Kenya: School of Education, Kenyatta University).

McLagan, P. (1996). Great Ideas Revisited. Training \& Development 50(1), 60-65.

Muduli, A., \& McLean, G. N. (2020). Training transfer climate: examining the role of high performance work system and organizational performance in the power sector of India. Benchmarking: An International Journal, ahead-of-print

Muduli, A., \& Raval, D. (2018), "Examining the role of work context, transfer design and transfer motivation on training transfer: perspective from an Indian insurance industry". European Journal of Training and Development, 42(3/4), 266-282.

Murphy, W. M. (2012). Reverse mentoring at work: Fostering cross generational learning and developing millenial leaders. Human Resource Management, 51(4), 549-574.

Phelps, E., Zimmerman, S., Warren, A. E. A., Jeličič, H., von Eye, A., \& Lerner, R. M. (2009). The structure and developmental course of Positive Youth Development (PYD) in early adolescence: Implications for theory and practice. Journal of Applied Developmental Psychology, 30(5), 571584.

Ragins, B. R., \& Kram, K. E. (2007). The roots and meaning of mentoring. In B. R. Ragins, \& K. E. Kram (Eds.), The handbook of mentoring at work: Theory, research and practice (pp. 3-17). Thousand Oaks: Sage Publications Inc.

Reagan-Porras, L. L. (2013). Dynamic Duos: A Case Review of Effective Mentoring Program Evaluations. Journal of Applied Social Science, 7(2), 208-219.

Redmond, S., \& Dolan, P. (2014). Towards a conceptual model of youth leadership development. Child \& Family Social Work, 21(3), 261-271.

Scobby, F. M. (2001). "Barriers to Transfer of Training to the Workplace".

Silbereisen, R. K., \& Lerner, R. M. (2007). Approaches to positive youth development. London: Sage Publications.

Singh, S. K., Mittal, S., Sengupta, A., \& Pradhan, R. K. (2019), "A dual-pathway model of knowledge exchange: linking human and psychosocial capital with prosocial knowledge effectiveness", Journal of Knowledge Management, 23(5), 889-914.

Smolter, V. (2011). Leadership development programs and generational differences (Master's thesis). The Pennsylvania State University. 
Sorensen, P. (2017). What research on learning transfer can teach about improving the impact of leadership-development initiatives. Consulting Psychology Journal: Practice and Research, 69(1), 47.

Soleman, M. (2019). Understanding Post-Training Factors and Job Performance Relationship: Review of Literature for Transfer of Training Enthusiasts

Theokas, C. (2005). Conceptualizing and Modeling Individual and Ecological Asset Components of Thriving in Early Adolescence. The Journal of Early Adolescence, 25(1), 113-143.

Yaghi, A., \& Bates, R. (2020). The role of supervisor and peer support in training transfer in institutions of higher education. International Journal of Training and Development.

Zakaria, U. K., Aziz, S. F. A., Selamat, M. N., \& Omar, N. H. (2020). Faktor Pemindahan Latihan Terhadap Prestasi Kerja Dalam Kalangan Anggota Jabatan Pengangkutan Jalan Negeri Selangor: Satu Kajian Teoritikal. International Journal of Entrepreneurship and Management Practices, 3(12), 01-08. 